\title{
Identifikasi Mikroorganisme Penyebab Infeksi Saluran Kemih pada Pasien Pengguna Kateter Urine di ICU RSUP Dr. M. Djamil Padang Periode 01 Agustus-30 November 2014
}

\author{
Inayah Afrilia ${ }^{1}$, Erly $^{2}$, Almurdi $^{3}$
}

\section{Abstrak}

Pasien rawat ICU sering membutuhkan pemantauan yang ketat, banyak dari mereka menggunakan kateter urine. Penggunaan kateter urine merupakan salah satu faktor risiko untuk terjadinya ISK. Tujuan penelitian ini adalah mengetahui mikroorganisme penyebab ISK yang terdapat pada urine pasien pengguna kateter urine di ICU RSUP Dr. M. Djamil Padang. Penelitian deskriptif ini telah dilaksanakan dari Februari 2014 sampai Desember 2014, meliputi pengambilan sampel di ICU RSUP Dr. M. Djamil Padang dan pemeriksaan bakteriologis sampel dilakukan di Laboratorium Mikrobiologi Fakultas Kedokteran Universitas Andalas. Data dianalisis secara deskriptif dan ditampilkan dalam bentuk tabel distribusi frekuensi. Hasil penelitian yang dilakukan terhadap 20 sampel dari pasien pengguna kateter urine, didapatkan bakteriuria bermakna sebanyak 11 sampel $(55 \%)$ dan tidak ditemukan bakteriuria sebanyak 9 sampel (45\%). Frekuensi ISK pada perempuan yaitu sebanyak 6 pasien (60\%), sedangkan pada laki-laki sebanyak 5 pasien (50\%). Frekuensi ISK pada pemakaian kateter selama $<7$ hari sebanyak 3 pasien $(33,3 \%), \geq 7$ hari sebanyak 6 pasien $(66,7 \%)$, $\geq 30$ hari sebanyak 2 pasien (100\%). Mikroorganisme penyebab ISK terkait kateter adalah Candida sp yaitu sebanyak 7 sampel (63,6\%), diikuti dengan Pseudomonas sp sebanyak 2 sampel (18,2\%), Escherichia coli dan Klebsiella sp masing-masing sebanyak 1 sampel (9,1\%). Simpulan penelitian ini adalah semakin lama pemakaian kateter akan semakin meningkatkan presentase ISK. Mikroorganisme penyebab terbanyak adalah Candida sp.

Kata kunci: Infeksi saluran kemih, mikroorganisme, kateter urine, ICU

\begin{abstract}
Patients in ICU frequently require careful monitoring, many of them use an urinary catheter. The usage of an urinary catheter is one of risk factor leading cause of Urinary Tract Infection (UTI). The objective of this study was to identify microorganisms that caused UTI in urine from patient with indwelling urinary catheter in ICU of Dr. M. Djamil Padang Hospital. This descriptive study was done in February 2014 to December 2014, involved taking the urine of catheter sample implemented at ICU of Dr. M. Djamil Padang Hospital and bacteriology examination of the sample implemented at Department of Microbiology, Medical Faculty of Andalas University. The result were analyzed descriptively and displayed in the form of frequency distribution tables. The results of the research from 20 samples from patient with indwelling urinary catheter, showed that significant bacteriuria counted 11 samples (55\%) and non bacteriuria counted 9 samples (45\%). Frequency UTI in female counted 6 patients (60\%), and in male counted 5 patients (50\%). Frequency UTI in patient with indwelling urinary catheter during $<7$ days counted 3 patients $(33,3 \%), \geq$ 7 counted 6 patients (66,7\%), and $\geq 30$ days counted 2 patients (100\%). Microorganisms that caused catheter associated UTI were Candida sp counted 7 samples (63,6\%), followed by Pseudomonas sp counted 2 samples (18,2\%), each Escherichia coli and Klebsiella sp counted 1 sample (9,1\%). The conclusion is increasing length of catheterization result in increased percentage UTI. The most microorganisms that associated UTI were Candida sp.
\end{abstract} Keywords: Urinary tract infection, microorganism, urinary catheter, ICU 
Affiliasi penulis: 1. Prodi Profesi Dokter FK Unand (Fakultas Kedokteran Universitas Andalas Padang), 2. Bagian Mikrobiologi FK Unand, 3. Bagian Patologi Klinik FK Unand

Korespondensi: Inayah Afrilia, Email: naya.afrilia@yahoo.com, Telp: 0812-6102-1703

\section{PENDAHULUAN}

Infeksi Saluran Kemih (ISK) merupakan infeksi yang sering ditemukan di tempat pelayanan kesehatan, baik pada pasien rawat jalan maupun rawat inap. ${ }^{1}$ ISK adalah keadaan yang menunjukkan keberadaan mikroorganisme pada saluran kemih yang ditandai dengan adanya kolonisasi bakteri di dalam saluran kemih. Bakteriuria merupakan indikator utama infeksi saluran kemih. Adanya bakteriuria bermakna menunjukkan pertumbuhan mikroorganisme sebanyak $\geq 100.000 \mathrm{cfu} / \mathrm{ml}$ pada kultur urine. Penderita dengan bakteriuria bermakna terkadang tanpa disertai tanda dan gejala klinis atau dapat disertai tanda dan gejala klinis ISK. ${ }^{2}$

Infeksi saluran kemih dapat menyerang pasien dari segala usia, perempuan lebih sering mengalami episode ISK daripada laki-laki, hal ini karena uretra perempuan lebih pendek. Prevalensi ISK meningkat secara signifikan dari $5 \%-10 \%$ pada usia 70 tahun menjadi $20 \%$ pada usia 80 tahun. $^{3}$ Diperkirakan 150 juta orang didiagnosis menderita ISK setiap tahunnya. ${ }^{4}$

Kejadian ISK pada penderita yang dirawat di rumah sakit, sering akibat infeksi nosokomial. Infeksi saluran kemih terjadi pada $35 \%$ dari seluruh infeksi nosokomial dan sekitar $80 \%$ diduga terkait pemakaian kateter. ${ }^{5}$ Pada pasien dengan pemasangan kateter selama kurang dari 7 hari, sebanyak 3\%-7\% berkembang menjadi ISK. Pemasangan kateter lebih dari 7 hari maka kejadian meningkat sebanyak $25 \%$, jika kateter dipasang sampai 30 hari maka $100 \%$ akan menjadi ISK. $^{6}$ Jika dibandingkan kateter sistem terbuka dan tertutup maka dalam 4 hari sebanyak 10\%-25\% penderita yang dipasang kateter sistem tertutup akan berkembang menjadi bakteriuria, sedangkan pada sistem terbuka bisa $100 \%{ }^{1}$

Infeksi nosokomial di Intensive Care Unit (ICU), lebih sering terjadi dibandingkan dengan bangsal. Kekerapan infeksi nosokomial di ICU tersering setelah infeksi saluran nafas adalah infeksi traktus urinarius. ${ }^{7}$
Pasien di ICU membutuhkan pemantauan yang ketat, khususnya pasien yang menggunakan kateter urine, akibatnya risiko infeksi saluran kemih pada pasien di ruang rawat intensif lebih tinggi dari pasien rawat lainnya. Pasien di ruang perawatan intensif umumnya adalah pasien dengan sakit berat dan komplikasi yang berarti, sehingga efek kateter terhadap menimbulkannya infeksi menjadi lebih kritis. ${ }^{8}$ Infeksi saluran kemih pada pasien rawat inap terutama disebabkan oleh pemasangan indwelling urineary catheter yang ikut memasukkan bakteri ke dalam traktus urinearius yang normalnya steril. Mikroorganisme gram negatif merupakan kuman yang paling sering ditemukan pada urine pasien dengan kateter, mikroorganisme tersebut meliputi Escherichia Coli, Proteus sp, Klebsiella sp, Serratia dan Pseudomonas sp. ${ }^{9}$

Kuman penyebab infeksi saluran kemih umumnya adalah kuman yang berasal dari flora normal usus dan hidup secara komensal di introitus vagina, prepusium penis, kulit perineum, dan sekitar anus. ${ }^{3}$ Infeksi dapat juga disebabkan kontaminasi bakteri pada tangan petugas medis dan perlengkapan medis. Bakteri patogen dapat memasuki saluran kemih melalui rute extra-luminal di sepanjang sisi luar kateter dan melalui rute intra-luminal di sepanjang lumen internal kateter dari kantong pengumpul atau dari catheter drainage tube junction yang terkontaminasi. Kondisi menetapnya kateter urine yang terpasang di saluran kemih menjadi media bagi bakteri untuk kolonisasi (biofilm). ${ }^{6}$

Kateter urine merusak pertahanan saluran kemih sebagai jalur artifisial untuk masuknya bakteri dengan laju pertambahan sebesar $3-10 \%$ per hari. ${ }^{10}$ Risiko infeksi saluran kemih meningkat sekitar $5 \%$ setiap harinya dari pemakaian kateter urine. ${ }^{11}$ Keadaan ini berdampak pada peningkatan mobiditas dan mortalitas, perawatan lebih lama dengan biaya perawatan lebih mahal. Infeksi saluran kemih dapat berkembang menjadi bakteriemia, sepsis dan kematian. ${ }^{12}$ Diperkirakan lebih dari 50.000 kematian terjadi setiap tahunnya di Amerika Serikat disebabkan oleh infeksi saluran kemih. ${ }^{13}$ 
Berdasarkan uraian diatas, maka perlu dilakukan penelitian ini untuk mengidentifikasi mikroorganisme yang terdapat pada urine pasien pengguna kateter urine di ICU RSUP Dr. M. Djamil Padang.

\section{METODE}

Jenis penelitian ini adalah deskriptif yang memberikan gambaran mengenai mikroorganisme penyebab ISK yang terdapat pada urine pasien pengguna kateter urine di ICU RSUP Dr. M. Djamil Padang. Penelitian dilaksanakan dari Februari sampai Desember 2014. Lokasi penelitian meliputi pengambilan sampel dilakukan di ICU RSUP Dr. M. Djamil Padang dan pemeriksaan bakteriologis terhadap sampel dilakukan di Laboratorium Mikrobiologi Fakultas Kedokteran Universitas Andalas Padang. Populasi dalam penelitian ini adalah semua pasien pengguna kateter urine di ICU RSUP Dr. M. Djamil Padang yang memenuhi kriteria inklusi. Sampel dalam penelitian ini adalah urine kateter dari pasien pengguna kateter urine di ICU RSUP Dr. M. Djamil Padang yang memenuhi kriteria inklusi. Teknik pengambilan sampel pada penelitian ini adalah secara consecutive sampling dengan besar sampel sebanyak 20 sampel. Kriteria inklusi adalah pasien rawat ICU yang menggunakan kateter urine $\geq 48$ jam. Sedangkan kriteria ekslusi adalah pasien yang telah didiagnosis sedang mengalami infeksi saluran kemih saat pemasangan kateter di ICU RSUP Dr. M. Djamil Padang. Pengumpulan data dimulai dengan pemilihan pasien berdasarkan kriteria inklusi dengan memeriksa riwayat pasien untuk pemilihan sampel urine kateter. Kemudian dilakukan pengambilan sampel dan pemeriksaan bakteriologis terhadap sampel. Pengolahan data dilakukan secara manual. Data yang diperoleh dari pemeriksaan urine kateter dikelompokkan berdasarkan jenis kelamin dan lama pemakaian kateter. Hasil yang diperoleh disajikan dalam bentuk tabel distribusi frekuensi dan dianalisis secara deskriptif untuk menarik kesimpulan.
HASIL

Berdasarkan hasil penelitian tentang identifikasi mikroorganisme penyebab infeksi saluran kemih pada pasien pengguna kateter urine di ICU RSUP Dr. M. Djamil Padang yang dilakukan di Laboratorium Mikrobiologi Fakultas Kedokteran Universitas Andalas, didapatkan hasil sebagai berikut :

Tabel 1. Frekuensi ISK berdasarkan pemeriksaan kultur urine kateter

\begin{tabular}{lcc}
\hline Diagnosis & Frekuensi & $\begin{array}{c}\text { Persentase } \\
\text { (\%) }\end{array}$ \\
\hline ISK & 11 & 55 \\
Non ISK & 9 & 45 \\
\hline Jumlah & 20 & 100 \\
\hline
\end{tabular}

Pada Tabel 1 dapat dilihat bahwa pemeriksaan terhadap 20 sampel urine kateter, didapatkan bakteriuria bermakna/ISK sebanyak 11 sampel (55\%). Sampel sisanya tidak ditemukan bakteriuria/non ISK sebanyak 9 sampel (45\%).

Tabel 2. Frekuensi ISK berdasarkan jenis kelamin

\begin{tabular}{lcccc}
\hline Diagnosis & \multicolumn{4}{c}{ Jenis Kelamin } \\
\cline { 2 - 5 } & \multicolumn{2}{c}{ Laki-laki } & \multicolumn{2}{c}{ Perempuan } \\
\cline { 2 - 5 } & $f$ & $\%$ & $f$ & $\%$ \\
\hline ISK & 5 & 50 & 6 & 60 \\
Non ISK & 5 & 50 & 4 & 40 \\
\hline Jumlah & 10 & 100 & 10 & 100
\end{tabular}

Tabel 2 memperlihatkan frekuensi ISK pada perempuan yaitu sebanyak 6 pasien (60\%), sedangkan pada laki-laki sebanyak 5 pasien (50\%).

Tabel 3. Frekuensi ISK berdasarkan lama pemakaian kateter

\begin{tabular}{ccccccc}
\hline \multirow{2}{*}{ Diagnosis } & \multicolumn{4}{c}{ Lama Pemakaian Kateter } \\
\cline { 2 - 7 } & \multicolumn{2}{c}{$<$ hari } & \multicolumn{2}{c}{$\geq \mathbf{7}$ hari } & \multicolumn{2}{c}{$\geq$ 30 hari } \\
\cline { 2 - 7 } & $f$ & $\%$ & $f$ & $\%$ & $f$ & $\%$ \\
\hline ISK & 3 & 33,3 & 6 & 66,7 & 2 & 100 \\
Non ISK & 6 & 66,7 & 3 & 33,3 & 0 & 0 \\
\hline Jumlah & 9 & 100 & 9 & 100 & 2 & 100 \\
\hline
\end{tabular}


Pada Tabel 3 dapat dilihat bahwa frekuensi ISK pada pemakaian kateter selama $<7$ hari sebanyak 3 pasien $(33,3 \%)$, $\geq 7$ hari sebanyak 6 pasien $(66,7 \%)$, $\geq 30$ hari sebanyak 2 pasien (100\%).

Tabel 4. Mikroorganisme penyebab ISK terkait kateter

\begin{tabular}{lcc}
\hline \multicolumn{1}{c}{ Jenis Mikroorganisme } & Frekuensi & $\%$ \\
\hline Candida $s p$ & 7 & 63,6 \\
Pseudomonas sp & 2 & 18,2 \\
Escherichia coli & 1 & 9,1 \\
Klebsiella sp & 1 & 9,1 \\
\hline Total & 11 & 100 \\
\hline
\end{tabular}

Tabel 4 dapat dilihat bahwa mikroorganisme penyebab terbanyak pada ISK terkait kateter adalah Candida $s p$ yaitu sebanyak 7 sampel $(63,6 \%)$, diikuti dengan Pseudomonas sp sebanyak 2 sampel (18,2\%), Escherichia coli dan Klebsiella $s p$ masing-masing sebanyak 1 sampel $(9,1 \%)$.

\section{PEMBAHASAN}

Berdasarkan hasil pemeriksaan laboratorium dapat diketahui bahwa dari 20 sampel urine kateter yang didapatkan dari pasien pengguna kateter urine di ICU RSUP Dr. M. Djamil Padang didapatkan ISK sebanyak 11 sampel (55\%). Hal ini mungkin disebabkan oleh tindakan instrumentasi transuretra (kateter menetap) yang merupakan faktor yang memudahkan organisme masuk ke dalam saluran kemih. $^{3}$

ISK didapatkan pada perempuan yaitu sebanyak 6 orang $(60 \%)$, sedangkan pada laki-laki didapatkan sebanyak 5 orang $(50 \%)$. Pada penelitian ini didapatkan presentase penderita ISK yang lebih tinggi pada perempuan dibandingkan dengan laki-laki. Perempuan lebih berisiko terkena bakteriuria karena uretra yang pendek dan secara anatomi dekat dengan vagina, kelenjar periuretral dan rektum. ${ }^{14}$ Kontaminasi ekstraluminal terjadi ketika mikroorganisme naik dari perineum ke sepanjang permukaan kateter dan paling sering terjadi pada perempuan. ${ }^{15}$ Kesulitan yang sering dialami pada tindakan kateterisasi perempuan yaitu pada waktu mencari muara uretra. Kateterisasi yang kurang hati-hati dapat menimbulkan lesi pada saluran kemih sehingga memudahkan terjadinya kolonisasi dan infeksi pada saluran kemih. ${ }^{3}$
ISK didapatkan pada pemakaian kateter $<7$ hari sebanyak 3 sampel $(33,3 \%), \geq 7$ hari sebanyak 6 sampel $(66,7 \%)$, dan $\geq 30$ hari sebanyak 2 sampel $(100 \%)$. Pada hasil penelitian ini terlihat semakin lama pemakaian kateter akan semakin meningkatkan presentase ISK. Risiko perhari untuk terjadinya bakteriuria dengan kateterisasi berkisar dari 3\%-10\% dan dapat mencapai $100 \%$ setelah 30 hari. ${ }^{8}$ Peningkatan lama perawatan dan lama kateterisasi adalah faktor independen yang berhubungan untuk berkembangannya infeksi saluran kemih nosokomial. ${ }^{13}$

Mikroorganisme penyebab terbanyak pada ISK terkait kateter adalah Candida $s p$ yaitu sebanyak 7 sampel (63,6\%), diikuti dengan Pseudomonas $s p$ sebanyak 2 sampel (18,2\%), Escherichia coli dan Klebsiella $s p$ masing-masing sebanyak 1 sampel $(9,1 \%)$. Penelitian yang dilakukan oleh Ding et al tahun 2009 juga menemukan fungi terutama Candida albicans $(33,3 \%)$ adalah patogen yang paling sering untuk infeksi saluran kemih terkait kateter, diikuti oleh Escherichia coli $(16,7 \%) .{ }^{16}$ Pola yang lebih kurang sama juga ditemukan Chen et al tahun 2012 bahwa Candida sp (31\%) adalah patogen infeksi saluran kemih terkait kateter yang paling sering, diikuti oleh Enterococcus $(10,1 \%)$ dan Escherichia coli $(9,9 \%) .{ }^{17}$ Candida $s p$ adalah patogen utama yang paling penting menyebabkan infeksi saluran kemih di ICU. ${ }^{13}$

Candida sp. merupakan bagian dari populasi komensal normal pada kulit, saluran gastrointestinal, dan saluran genital wanita. Candida sp. dapat menyebabkan infeksi yang berhubungan dengan pemberian terapi antimikroba berspektrum luas pada pasien di unit rawat intensif (ICU). Setelah pemakaian antimikroba spektrum luas, fungi dapat tumbuh secara berlebihan dan berkembang menjadi infeksi. Pasien dengan defisiensi imun adalah yang paling rentan terhadap hal ini. ${ }^{18}$

Penggunaan agen antibakteri spektrum luas secara dini dan empiris pada pasien dengan sakit kritis dan pemberian awal flukonazol adalah faktor umum yang berkontribusi terhadap peningkatan frekuensi isolasi patogen resisten. Penggunaan kateter indwelling meningkatkan kerentanan untuk terjadi patogen multi drug resistance dan berhubungan dengan terbentuknya biofilm. ${ }^{17}$ 
Mikroorganisme bisa memasuki saluran kemih melalui rute ekstra luminal yaitu migrasi disepanjang sisi luar kateter di mukosa periuretra atau melalui rute intra luminal yaitu migrasi disepanjang lumen dalam kateter dari kantong pengumpul yang terkontaminasi atau catheter-drainage tube junction yang terkontaminasi. Pembentukan biofilm oleh patogen urin terjadi secara menyeluruh dengan perpanjangan durasi kateterisasi. Dari waktu ke waktu, kateter urine akan dikoloni dengan mikroorganisme yang hidup di dalam biofilm, menjadikan mereka resisten terhadap antimikroba dan pertahanan tubuh sehingga tidak mungkin untuk dibasmi tanpa melepaskan kateter. ${ }^{8}$

Kateter urine tidak hanya menyebabkan terbentuknya biofilm, tapi keberadaan kateter sendiri merusak banyak mekanisme pertahanan normal kandung kemih. Kateter urine menghubungkan perineum yang banyak koloni dengan kandung kemih yang normalnya steril, dan menyediakan rute untuk masuknya bakteri disepanjang permukaan dalam dan luar kateter. Pada kateter yang terpasang, urine sering menggenang di kandung kemih atau di kateter sendiri, keadaan statis urine mendorong bakteri berkembang biak. Penyumbatan kateter dapat menyebabkan distensi dan iskemi pada mukosa kandung kemih, demikian meningkatkan kerentanan untuk invasi oleh mikroorganisme. Kateter juga merusak mukosa kandung kemih dengan memicu respon inflamasi dan erosi mekanik. Kejadian bakteriuria tidak dapat dihindari selama kateter urine masih terpasang. ${ }^{8}$

\section{SIMPULAN}

Mikroorganisme penyebab ISK terbanyak adalah Candida sp yaitu sebanyak 7 sampel $(63,6 \%)$, diikuti dengan Pseudomonas sp sebanyak 2 sampel $(18,2 \%)$, Escherichia coli dan Klebsiella sp masingmasing sebanyak 1 sampel $(9,1 \%)$.

\section{DAFTAR PUSTAKA}

1. Kuntaman, Muhardi E, Harsono S, Debora K, Mertaniasih NM. Aspek mikrobiologi pada infeksi saluran kemih. Dalam: Nasronudin, Hadi U, Vitanata, Bramantono EA, Suharto, Soewandojo E, editor (penyunting). Penyakit Infeksi di Indonesia:
Solusi Kini \& Mendatang. Surabaya: Airlangga University Press;2007.hlm.166-70.

2. Sukandar E. Infeksi saluran kemih pasien dewasa. Dalam: Sudoyo AW, Setiyohadi B, Alwi I, K Simadibrata M, Setiadi S, editor (penyunting). Buku ajar ilmu penyakit dalam. Jilid II. Edisi ke-5. Jakarta: Interna Publishing; 2009.hlm.1008-15.

3. Purnomo BB. Dasar-dasar urologi. Edisi Ke-2. Jakarta: Sagung Seto; 2003.

4. Zaslau S, Uzelac PS. SOAP untuk urologi. Jakarta: EGC;2010.hlm.94-6.

5. Piljic D, Jahic HP, Piljic D, Ahmetagic S, Jahic R. Catheter-associated urinary tract infections in adults. Mater Sociomed. 2013;25(3):182-6.

6. Jaggi N, Sissodia P. Multimodal supervision programme to reduce catheter associated urinary tract infections and its analysis to enable focus on labor and cost effective infection control measures in a tertiary care hospital in India. Journal of Clinical and Diagnostic Research. 2012;6(8): 13726.

7. Zulkarnain I. Infeksi nosokomial. Dalam: Sudoyo AW, Setiyohadi B, Alwi I, K Simadibrata M, Setiadi $\mathrm{S}$, editor (penyunting). Buku ajar ilmu penyakit dalam. Jilid III. Edisi ke-5. Jakarta: Interna Publishing; 2009.hlm.2906-10.

8. Lee JH, Kim SW, Yoon BI, Ha US, Sohn DW, Cho $\mathrm{YH}$. Factors that affect nosocomial catheterassociated urinary tract infection in intensive care unit: 2-year experience at a single center. Korean Journal of Urology. 2013;54:59-65.

9. Sears BW, Spear L, Saenz R. Intisari mikrobiologi dan imunologi (terjemahan). Jakarta: EGC; 2011. hlm. 64-6.

10. Guggenbichler JP, Assadian O, Boeswald M, Kramer A. Incidence and clinical implication of nosocomial infections associated with implantable biomaterials - catheter, ventilator - associated pneumonia, urinary tract Infections. GMS Krankenhaus. 2011;6(1):1863.

11. Saint S, Meddings JA, Calfee D, Kowalski CP, Krein SL. Catheter-associated urinary tract infection and the medicare rule changes. Ann Intern Med. 2009;150(12):877-84.

12. Mody L, Saint S, Galecki A, Shunchen, Krein SL. 
Knowledge of evidence-based urinary catheter care practice recommendations among health care workers in nursing home. Jurnal Compilation The American Geriatrics Society. 2010;58(8):1532-7.

13. Laupland KB, Bagshaw SM, Gregson DB, Kirkpatrick AW, Ross T, Church DL. Intensive care unit-acquired urinary track infections in a regional critical care system. Critical Care.2005;9:60-5.

14. Price SA, Wilson LM. Pathophysiology: clinical concepts of disease processes. Vol 2. Edisi ke-6. Mosby: Elsevier Inc; 2006.hlm.912-47.

15. Mathur S, Suller MT, Sticler DJ, Feneley RC. Genotyping of urinary and fecal Proteus mirabilis isolates from individuals with long-term urinary catheter. Europe Jurnal Clinical Microbiology Infections Diseases. 2005;24(9):643-4.
16. Ding JG, Sun QF, Li KC, Zheng MH, Miao XH, Ni $\mathrm{W}$, et al. Retrospective analysis of nosocomial infections in the intensive care unit of a tertiary hospital in China during 2003 and 2007. BMC Infectious Diseases. 2009;9:115.

17. Chen YY, Chen LY, Lin SY, Chou P, Liao SY, Wang FD. Surveillance on secular trends of incidence and mortality for device-associated infection in the intensive care unit setting at a tertiary medical center in Taiwan, 2000-2008: A retrospective observational study. BMC Infectious Diseases. 2012;12:209.

18. Gillespie S, Bamford K. At a glance mikrobiologi medis dan infeksi. Edisi Ke-3. Jakarta: Erlangga; 2009.hlm.32-57. 